\title{
First report of tomato spotted wilt virus in Argyranthemum frutescens in China
}

\author{
Yan Liang ${ }^{1} \cdot$ Chen-Qing Yuan ${ }^{1} \cdot$ Li-Fang Li $^{1}$ \\ Received: 24 May 2019 / Accepted: 25 November 2019/Published online: 3 January 2020 \\ (C) The Author(s) 2020
}

Keywords TSWV $\cdot$ DAS-ELISA $\cdot$ RT-PCR $\cdot$ Argyranthemum frutescens

Argyranthemum frutescens, a member of Asteraceae family, is a popular ornamental plant grown in public parks. In December $2018,5 \%$ to $10 \%$ of plants, grown in a glasshouse in Shunyi District, Beijing, China, showed virus-like symptoms, such as yellowing, mottling and internode shortening. Leaves collected from six symptomatic plants were tested for several common viruses that infect ornamental plants including cucumber mosaic virus (CMV), tobacco mosaic virus (TMV), tomato spotted wilt virus (TSWV), and Impatiens necrotic spot virus (INSV) by DAS-ELISA (Agdia). Among the naturally infected A. frutescens plants, only TSWV was detected while CMV, TMV and INSV were not. To further confirm the TSWV infection, RT-PCR was performed using the following specific primers (Yin et al. 2013; TSWV-L-F: 5'- ACTGCCAT AGGACTTTTGACC-3', TSWV-L-R: 5'-ACGGCTCT ATAGGAGAGGTC-3'; TSWV-M-F: 5'-AGGGCTAG TGATGCTTACAG-3', TSWV-M-R: 5'-TCACAATT GCCCTGAGTTC-3') designed to amplify portions of TSWV genome segments. As a result, $680 \mathrm{bp}, 863 \mathrm{bp}$ and $650 \mathrm{bp}$ products of the TSWV L RNA, M RNA and S RNA genome segments, respectively, were detected from all diseased samples, which were then cloned and sequenced. BLASTn analyses revealed that the partial RdRp gene sequence (MK936047) of TSWV-L RNA had the highest nucleotide similarly of 94 99\% with isolates from different hosts in Beijing (MK433644), Spain (KP008130), Italy (KJ575619; MH763621). The TSWV-M fragment sequences (MK936048) obtained from GenBank database showed a 96\%-99\% similarity with isolates from different hosts in South Korea (KC261948; KC261963) and Spain (KP008133; AY744493). The TSWV-S fragment (MK693040) was 97\%-99\% identical to that of tomato and

Li-Fang Li

371094901@qq.com

1 Beijing Florascape Co., Ltd., Beijing, China pepper isolates from Spain (AY744479-80; DQ376184-85), pepper isolates from Italy (DQ915946; HQ839729-30), and various plants isolates from USA (KU179513-15; AY744468-75). At the amino acid level, RdRp protein (L RNA) showed $100 \%$ identity with the same Beijing isolate (QED87911). Glycoprotein precursor protein (M RNA) was 99\% identical to a South Korea isolate (AGM53757). Nucleocapsid protein (S RNA) showed a $99 \%$ similarity with a Spain isolate (AAU95401). TSWV is one of the top ten plant viruses which leads to huge economic losses (Rybicki 2015) and although it is known to infect other hosts in China hosts it was not previously reported in A. frutescens. To our knowledge, this is the first report of TSWV infections in A. frutescens in China.

Open Access This article is licensed under a Creative Commons Attribution 4.0 International License, which permits use, sharing, adaptation, distribution and reproduction in any medium or format, as long as you give appropriate credit to the original author(s) and the source, provide a link to the Creative Commons licence, and indicate if changes were made. The images or other third party material in this article are included in the article's Creative Commons licence, unless indicated otherwise in a credit line to the material. If material is not included in the article's Creative Commons licence and your intended use is not permitted by statutory regulation or exceeds the permitted use, you will need to obtain permission directly from the copyright holder. To view a copy of this licence, visit http://creativecommons.org/licenses/by/4.0/.

\section{References}

Rybicki EP (2015) A top ten list for economically important plant viruses. Arch Virol 160(1):17-20

Yin YY, Dong JH, Xu XY, Duan YM, Zhang ZK (2013) Genetic diversity analysis of $\mathrm{N}$ gene in different isolates of TSWV from Kunming (in Chinese). SCAS 26(1):159-162

Publisher's note Springer Nature remains neutral with regard to jurisdictional claims in published maps and institutional affiliations. 